\title{
$0 \mathrm{M}$ オート ドッファの開発の経過と
}

\section{機構機能およびその特長*}

1. 概磁

国の発展は産業にあり，産業の発展の基幹が工業にあ ることは誰しす異論はないはずである。その工業が旧態 依然たる施設や経営に依存していては, その使命を全う することができない，特に最近の自由化開放貿易による 国際情勢経済情勢の推移の度がしわつとなるにつれて, これに対応する拔本的合理化対策を樹立せねばならな い. この方途そ，して基本的な生産性の合理的諸問題を検 討配虑して，実施せさるを得ないのが現状である。すな わら自動機械化により高性能, 高能率化し工費の節減, コストの低減，生産の安定性，確実性をはからねばなら ない，紡績業界に和いてもしかりであり，その直接生産 工程の構造をいかにすべきかに多角的な検討が加えられ つつあるが, さらに未来の無人紡續時代を夢想し，紡績 業者就よび鐵維機械製造業者が日夜飛躍的な革新開発に 鋭意努力しつつある現状である，この無人䊉績の理想像 は一端に原綿を投入すれば開俵, 開綿, 混綿, 梳綿, 練 条, 精紡, 巻返し, 合系ねん糸, 整経, 織布, 染色仕上 などの工程が連続自動化され，なんら人手を要しないと いうものである。現時点に和いてもこの夢の合理化自動 化対策の過程として全自動化ではないが，各社により翼 なれどす少なくとも数機種の連続自動化が実施され，す でに稼動していることは采知である.

このような自動化用諸機械および装置の実施計画にあ たり，OMの留意している要点は次の通りである.

（1）機種，台数，取报い労力を最少ならしめるよう 機械を選定配置し，高性能高能率が保持できるよ5にす る.

（2）機械の現在，未来に扚ける生産力の増大に対応 して調和がとれるようにする.

（3）各機相互間の材料和よび製品の受渡しが円滑か
会員新井武治**

つ能率的に行なわれること。

（4）各機の作動状態拉よび各機間生産品の状態を検 知し，制御または処理する装置を備え，品質管理を自動 的または容易ならしめる様式にすること。

（5）、トラブルの要因になり勝ちな各機械ならびに室 内の清掃が自動的に行なわれること。

（6）各機戌装置の保全管理が簡単容易であること.

当社は以上の要索に基いて，終局目標の具体化につい てすでに大きな貴献をしている，すなわち最す人手を要 する部分の自動化の研究開発に成功し，実働化の実績を 持っている、それは高性能のカード，しのむら自動制御 補正装置付高速練条機，練条機ケンスの自動交換装置， 自動スライバ継ざ装置, ケンス自動循環供給装置, 一台 一斉交換式ヶンスクリールを使用したスライバッー ヤーン式精䊉機,ケンスクリールの運撽を兼ねたオート ドッブ, 同上用ボビンローディング ステーション, 同上用ボビンソータ，ボビンローディング ステーシ シンからワインダへの供給, ワインダより空木管をボビ ンソータへの供給などの工程がすべて完全自動化され ている.

\section{OMオートドッファの開発の経過につ いて}

これより自動化の一部分である精紡機およびねん糸機 用の.OMオートドッフフについてのべる。

尊知のようにオートドッファには操作面に括いて種 々あり，1錘式のすの，6１2鉷式のもの，全台一斉操 作式などがあり，OMドッフフは後者に属し全台一斉操 作式のbのである。しかしながら本ドッファはドッフィ ングおよびドニングをするばかりでなく，空木管または 空紙管ならびに満管系管の選別運搬, 供給および次工程 への連倸がすべて自動的操作が容易であり，検知装置の

* How OM-type Auto-doffers Was Perfected. Its Mechanism and Characteristics.

** T. Arai, Member. オーェム製作所 
付備し得られるのが特長である.

OMオート ドッフォは1955 年にアメリカのサウスカ ロライナ州スパタンパーグに所在するディアリングミう ケンリサーチコーポレーションが紡績学務者の不定着, 求人難，労務营高騰に対処する企業の安定性を企画検討 され長期計画案として全自動化を目標としなかでるる っとす人手を要する玉揚作業の機械化に重点を膡いて 開発に着手され，卓越した技術力之数意の巨費を投じて 1959年に同地,同社のドレイトンミルに拈ける既設建物， 既設機械（ 3 線式 $31 / 2$ in $\times 238$ 錘綿精紡機 4 台 $\times 6$ 列） に実際の操業に活用され予期以上の成果をあけ゚得た。 同社ではこれに力を得てさらに工程の短縮と合理化方法 を検討されつつある折り，1960年にたまたま来日された 京社副社長がオーエムの梳綿機とレイルウエイ ヘッド により連結されたオートイプナ付練条機に関心を持たれ て翰出契約が成立し，納入後該機の成果があげ得られる のが結緣となり，さ らに当社のスライバ ッーヤーン方式の 優位性が認められる と共に,オートドッ フォとの組合せに当 社開発のポータブル クリールを使用する ことが効果がさらに あがり，一段とその 喡力を加え得られる ことの確認が雨者間 にされ，1961年に才 一トドッファの技 術提㩲が成立した。 現在稼動している OMドッフォは，フ メリカサウスカロ イナ州スパタンバー グのドレイトンミル に5 台, 同じくスパ タンバーグにあるプ ロットタイプミルに 2 台, 日本に和いて は日東紡広工場比 1 台で据付中肪よび製 作中のものが10数台
におよんでいる.

\section{OMオート ドッファ採用について}

OMオートドッフォを採用する場合精䊉機なよびね ん米機の配列は第 1，2図のごとき2つの方法がある. 第 1 図の場合は精紡機括よびねん系機の長手方向に稼動 するすので，機台拉よぴ床上の清掃が可能であり，第 2 図の場合はドッファに清掊装置が装備できないが，操作 台数が約 $25 \%$ 增加し得られる．それは同一操作台数であ ればキャリヤ走行巨離が短かくてすむからである，機台 配列によりドッファの構造が異なり，第 1 図の場合の 造はドッフォフレームとドッフォキャリヤとの組合せ により綎横左右に稼動することを可能ならしめる，第 2 因の場合にはドッフォフレーム自体が左右走行稼動可 能なるようにするのみであるからすずて構造も簡単で ある。

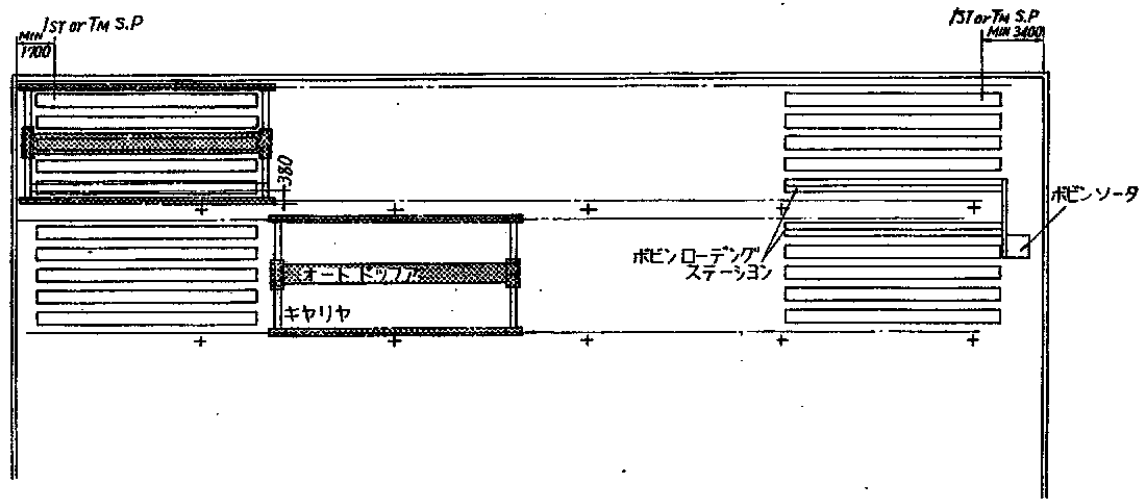

（第１（図）

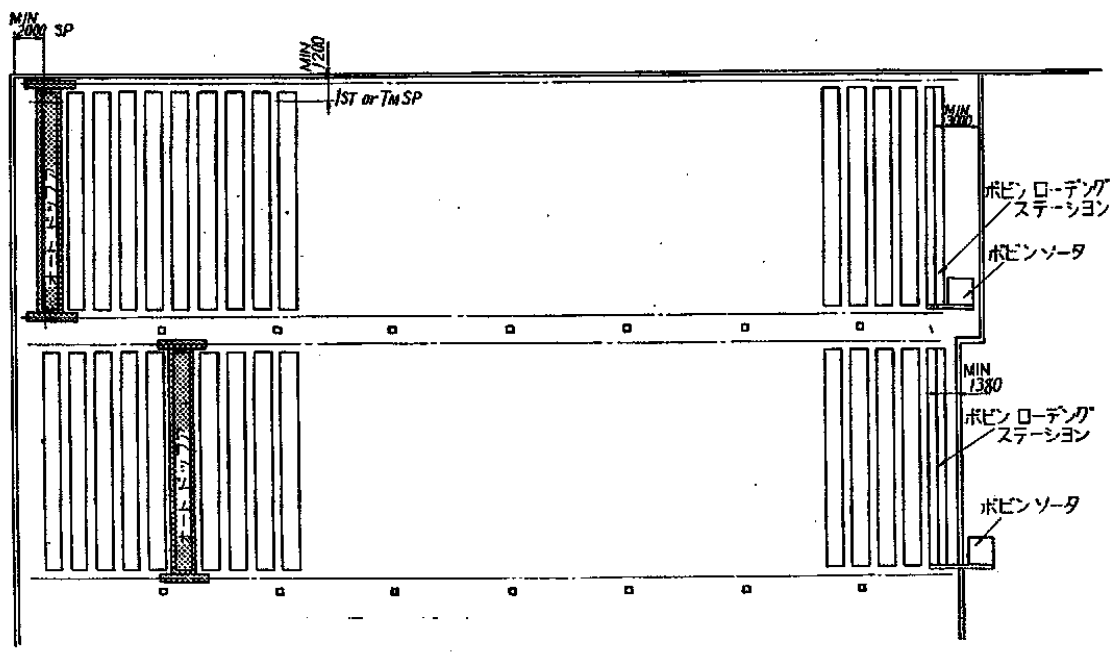

(第 2 図) 
4. オートドッファとエ場の構造ならびに 機台との関係

（1）オート ドッフォを効率よく使用するためには， オートドッフォで取り报われる精紡機台数が全部 1 区 画内にあって,この中に柱があってはならない、一区画 内の持台数が少な過ぎる場合には建物の構造にすよるが 1台のドッファで二区画を稼動させることるできる特殊

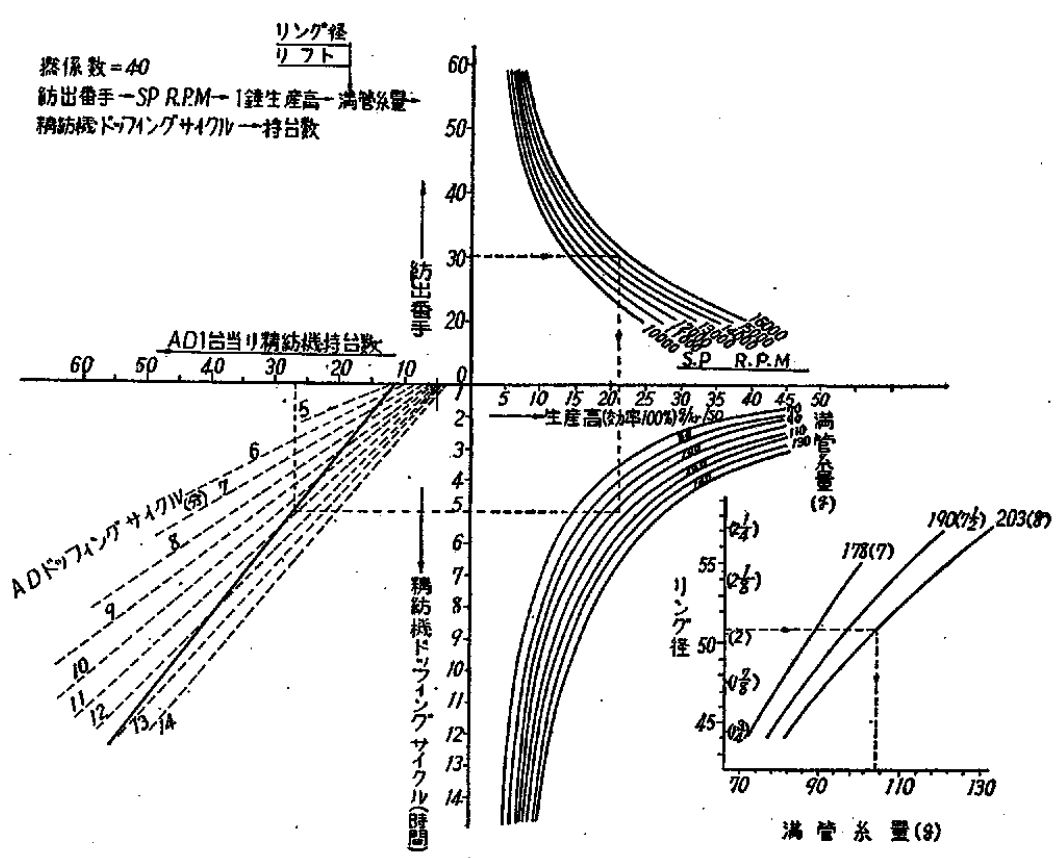

(第 3 図) OMオートドッフォ1 台当り精紡機持台数概算グラフ

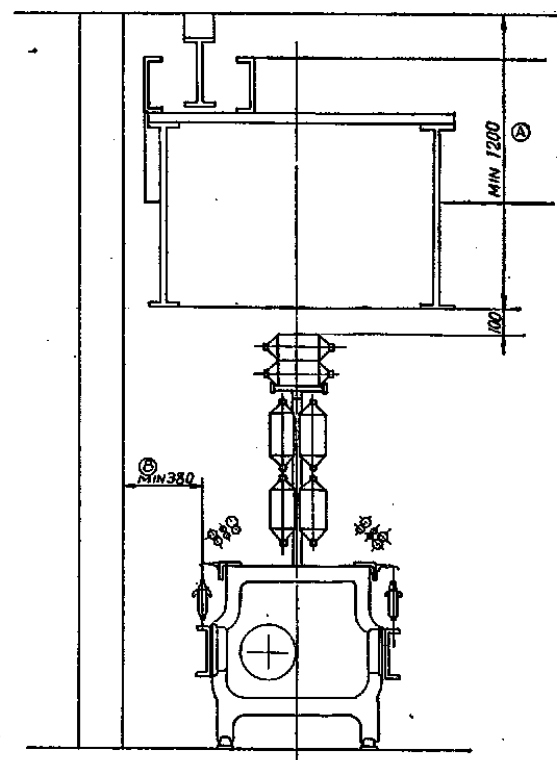

(第 4 図)
の場合もある.ただしこの場合ドッファキャリヤは2 台要る。(第 3 図参照)

（2）同一のオートドッフォで稼動させる精紡機の スピント゚ルピッチおよび鋎数は同一でなけ机ばならな い. 紡出番手，リング径、リフトは必ずしる同一でなく とすいが, ボビンローディングステーションが複雑 になる。

（3）精紡機台上にオートドッフォキャ!ヤの走行 するスペースが $1200 \mathrm{~mm}$ は必要である（第 4 図参 照)

（4）柱または壁面とス ピント゚ルの距離は最小 380 mm は必要である。（第 4 図参照) ただし(3)ど(4) の条件は互いに関係があり 両者を最小限にすることは できない、しかしながら各 機台間のスペースは歩行に さしつかえなければ，いく ら挟くてもドッフォの制約 を受けない。

(5) 建物汇ドッフの 重量が 8〜10ktonかかる゙の でこれを支持する強度が必 要である.しかし1本の柱 にかかる重量は $2 \sim 4$ kton であるので不足の場合は補強で足りる。

（6）. 据付上建物括よびその他の関係はほぼ第 1，2， 4図の通りである。

\section{5.オートドッファの作動と精紡機な.らび にねん糸機に関して}

(a) スピンドル上にグラスパレールが下降するに 要するスペースが必要であるクリール，ローラ゙パート， ラペット（反転した時）などを含み第 5 图 ( 寸法が 40 $\mathrm{mm}$ 以内に何物もないことが望ましい。多少はグラスパ レールの下降方法を変更して使用することができるが, なるべく上記寸法以上を希望する。

（b） セパレータは普通の場合倒す必要か゚ないが，ス ピソドル ピッチとリング 径の関係が下記範囲であるこ とが望ましい。

(スピンドル ピッチ)ー(リング径 $)=25 \mathrm{~mm}$ 以上 
セパレータの構造により最小

$20 \mathrm{~mm}$ をで可能でるあ.

(c) アンチノードリン グはドッフィングのとき大体 第 4 図(D寸法 $25 \mathrm{~mm}$ まて下 げ得ることが望ましい。

(d) リングレールはド ッフィングの際, 尻巻き数を $5 \pm 1$ 巻程度の精度で行なう ことができる場合は第 5 図因 寸法のごとく, ボビンに展巻 きを行なってもよいが巻数が 規正できないときはさらに下 降さして，スピンドルブレ ードに巻き付けなければなら ない.

(e) オートドッフォ呼 出乙用の予報接点付オート カウンタを取付ける必要がある。

（f）精紡機またねん系機のGEとOEとの両側に， グラスパ レールガイト゚ ポストを取付ける必要がある. 普通の機台であれば取付け可能である.

（g）大略以上の条件がまんそくでさるならば，容易 にOMオートドッファは使用でさるが，採用に当って は工場建物，工場内部構造物（たとえば照明関係，温調 関係) 機台なと゚の検討が必要である.

\section{OMオートドッファの鞿構性能につい} $\tau$

OMオートドッフォの機構は前記したごとく, 精紡 機またはねん米機台の上をすなわらドッフィング ドニ ングをすべき機台上を綎横左右に走行して，機台の直上 上り全台一斉操作が行なわれるるのであるので，普通機 台（5節の条件を具備した）にグラスパレールガイド ポストのみ取付ければその目的が達し得られる.このよ らな動作をするためにはグラスパ（満管糸管怙よび空木 管または空紙管をはじする器で，鉄パイプの内側にラバ 一チューブの入ったもので, 压搾空気の压力によって 内僋に膨張させ，管禾または木管をあたかる手力たよっ てはじしたごとく軟く，しかも強くつかんで引抜いたり または離して一定圧の压力でそう入したりするるの）を 機台片側の総鍾数と同一数をグラスパレールに取付け て，鯜レールを上下前後に動作さして，ドッフィング括
よびドニングをさするのである.グラスパ レールを前 後に動かす意味は該レールKフルボビン用と,インプ ティボビン用グラスパとが取付けてあるので, 最初に フル ボビンをスピンドルから抜きインプティ ボビンを そう入するためにスピンドル中心より前面に移動させな ければならぬためである. 該レールを作動させるために ドッファキャリヤ（特殊クレンの一種であって空気王 縮機, 油圧ポンプ, 油圧シリンダ, キャリヤ自体走行装 置, 自動制御, 電気装置関係などを装備されている) よ り油圧シリソダに連係された $3 \mathrm{~mm}$ の特殊ワイヤロー プ片側 8 本によって滑車を介し一斉昇降させる機構であ る.

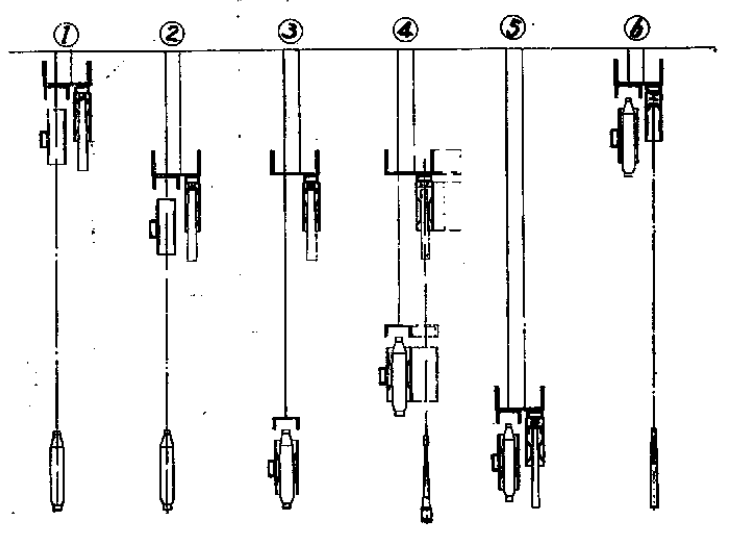

（第 5 図）グラスパ ドッフィング順序

\section{OMオート ドッファの作動について}

OMオートドッファは满管機台から满管時刻の約 10 min前に発せられる予告信号を受けると，空ボビンをは じしたドッフっはその機台を探知し，自動的にその真上 に到達して待機する．作業員がペンダントを下しボタン 操作によりドッフォレールは降下し,その外側 2 列のフ ルボビシ用グラスパにより，全鍍から管系を一斉につ かみ上げ，ついで内側 2 列の空ボビン用グラスパにより 全錘一斉に空ボビンをそ5入する.こうしてドッフィン グが終わると渪管糸管をはじしたまま口ーディング ス テーション向って自動進行し定位置に自動停止し, 作業 員の操作によりグラスパ レールを引下げてローディン グステーション上のペック゚に満管糸を放固させ，同時 に内側ペッグ上に放置されたるインプティボビンをは じさせ該レールを引揚げると同時に自動的に進行し，つ ぎの满管信号を受けるをで清掃動作を自動的に繰返して いるか, またはローディングステーション上で待機す る. 上記清掃可能にするためにはドッファと機台とが直 
角方向に据付けられた場合のみであって，これを装備し た場合には機台，天井，床の高能率なクリーニングをさ せることができる、またOM一S型ズライバッーヤー ソ精紡機を使用する場合スライバを収容したスモール ケンス，空ケンスを全錘分をポータブルクリールにの せたままドッフォで吊上け゚，吊下して交換することもで きる.ローディング ステーションはドッフォから满管系 管を受け取ったり，空木管を補給する装置で精紡機と同 一ビッチ，同一錘数のペッグが 4 列に並び外側がフルボ ビン用，内傊が空木管用であってボビンソータから空木 管を受忖取り，同時に満管系管を次工程に引渡す作業を する装㯰であってドッフォとの組合わせとなっている.

\section{8. $\mathrm{O} M$ ドッファの特長について}

（1）構造が簡単で操作に熟練を要せず，また機能が 確実で故障の発生がない。

（2）ボビン，管系の選別，装てん括よび運搬は一切 自動的に行なわれる。

（3）采の種類，番手，リング径、リフトに対する融 通性が大である。

（4）全錘一斉から全自動操作であるから，錘数に関
係なく所要時間が短い。

（5） ポビンおよび管糸は全周面ではあくするので 損偟がなく，半玉でる玉揚げできる。

（6）玉揚方向が垂直であるから糸切れが少なく，y ング、スピンドルの心出しを社わさず，再調整の必要が ない.

（7） 1 名の作業員で多数の機台を処理することがで きる.

（8）室内执よび機台の清掃を自動的に行なわせるこ とができる。

（9）スライバッーヤーン方式ではケンスの交換も 一斉に行なわれる.

（10）精紡一オートワインダ間の連続自動化が容易 である.

（11）玉丙揚容器や台車が不要である。

（12）一錘管理が可能である.

9. ドッファの使用動力

ドッファ走行用 $3 \mathrm{~kW}$ 電動機 油压ポンプ用。 $3.7 \mathrm{~kW}$ 電動機

空気圧縮機用 $2.2 \mathrm{~kW}$ 電動機 